\title{
Analisis Unjuk Kerja Oven Pengering Hasil Modifikasi Dengan Variasi Kecepatan Aliran Udara Panas
}

\author{
Kemas Muhammat Abdul Fatah* \\ Program Studi Teknik Mesin, Universitas Sang Bumi Ruwa Jurai \\ Jln. Imam Bonjol No.486 Langkapura Bandar Lampung, Lampung, 35118, Indonesia \\ E-mail: kmsmafattah@gmail.com
}

\section{Info Naskah:}

Naskah masuk: 14 Juni 2020

Direvisi: 2 Agustus 2020

Diterima: 13 Agustus 2020

\begin{abstract}
Abstrak
Efisiensi biaya produksi melalui modifikasi oven pengering dengan memanfaatkan economizer sebagai sumber panas proses pengeringan, sehingga komponen biaya bahan bakar solar dihilangkan. Penelitian ini ditujukan untuk mengetahui unjuk kerja oven pengering hasil modifikasi yang dikaitkan dengan mutu produk yang dihasilkan yang diukur dari tingkat kekeringan yang dicapai. Dari 3 (tiga) eksperimen yang dilakukan dengan variasi pada kecepatan aliran udara panas yaitu $0.5 \mathrm{~m} / \mathrm{dtk}, 0,7 \mathrm{~m} / \mathrm{dtk}$, dan 0,9 $\mathrm{m} / \mathrm{dtk}$, ditemukan bahwa pada hanya eksperimen pertama terjadi kondensasi dan produk hasil pengeringan dinyatakan NG. Dari hasil hipotesis independent sample t-test menyimpulkan tingkat kekeringan produk hasil eksperimen ketiga lebih baik dari produk hasil eksperimen kedua. Sehingga, setting laju aliran udara panas sebesar 9 $\mathrm{m} / \mathrm{dtk}$ menghasilkan unjuk kerja oven pengering hasil modifikasi yang paling optimal.
\end{abstract}

\section{Keywords:}

air flow;

efficiency;

quality;

t-test.

\section{Abstract}

Cost production efficiency through modified tunnel driyer by using the economizer so that the cost of fuel component eliminated. This study aimed to determine the performance of modified tunnel driyer associated with the quality of the product produced related to achived drying rate . From 3 (three) experiments conducted with variations in the hot air flow velocity of $0.5 \mathrm{~m} / \mathrm{sec}, 0.7 \mathrm{~m} / \mathrm{sec}$, and $0.9 \mathrm{~m} / \mathrm{sec}$, it was found that only the first experiment occurred condensation and the resulting drying product was declared NG . From the results of the hypothesis independent sample t-test concluded the level of dryness of the results of the 3rd experimental product is better than the results of the 2 nd experimental product. Thus, setting a hot air flow rate of $9 \mathrm{~m}$ / sec produces the most optimal modified dryer performance. 


\section{Pendahuluan}

Industri obat nyamuk merupakan industri potensial dengan nilai pasar mencapai Rp. 5 triliun, 4 (empat) dari 10 (sepuluh) rumah tangga di Indonesi menggunakan obat nyamuk. Dari keseluruhan pengguna obat nyamuk, $40 \%$ merupakan obat nyamuk bakar atau berbahan coil dengan nilai pasar mencapai 2 triliun. Penggunaan obat nyamuk bakar tidak hanya didominasi oleh kalangan ekonomi bawah tetapi juga kalangan ekomemi atas, tidak hanya di pedesaan juga diperkotaan [1].

Ada banyak produk obat nyamuk bakar yang beredar di Indonesia, diantaranya obat nyamuk merek Baygon, HIT, Tiga Roda,Vape, Cap Dua Kingkong dan Domestos No Mos dan lain sebagainya [2]. Dengan begitu banyaknya merek obak bakar yang beredar dipasaran tentu memunculkan kompetisi (competition), dimana kompetisi yang dimaksudkan adalah persaingan antar perusahaan yang muncul untuk memperoleh sesuatu yang tidak dapat diperoleh semua [3], dalam hal ini adalah persaingan di dalam memperoleh pangsa pasar obat nyamuk.

Agar perusahaan dapat unggul dalam bersaing maka setiap perusahaan akan menjalankan strategi bersaing yang dianggap akan mampu membawa perusahaan untuk dapat memenangkan persaingan pasar, salah satu strategi yang dapat dipilih adalah strategi kepemimpinan biaya (Cost Leadership). Perusahaan yang mengadopsi strategi kepemimpinan biaya bertujuan untuk meningkatkan pangsa pasar berdasarkan menciptakan posisi biaya rendah dibandingkan dengan perusahaan sejenis [4]. Namun demikian, strategi kepemimpinan biaya hanya mungkin ketika manajer di sektor manufaktur menekankan pada implementasi Quality Management (QM) di perusahaan mereka, dengan salah satu unsurnya adalah continuos improvement [5].

Pemanfaatan energi panas terbuang (waste heat) pada proses pengeringan obat nyamuk bakar adalah salah satu cara yang dapat dilakukan di dalam upaya continuos improvement. Dalam hal ini, pemanfaatan energi panas terbuang dalam proses industri, salah satu tujuannya adalah untuk mengurangi konsumsi bahan bakar untuk peningkatan efisiensi produksi. Adapun sumber-sumber energi panas yang terbuang dapat berasal dari regenerative and recuperative burners, economisers, waste heat boilers, air preheaters, plate heat exchanger, heat pipe systems, Heat Recovery Steam Generator (HRSG), thermodynamic cycles used for waste heat recovery, heat pumps, direct electrical conversion devices [6].

Banyak penelitian telah dilakukan di dalam memanfaatkan energi panas terbuang, misalnya; memanfaatkan panas terbuang dari kondensor pendingin udara untuk mengeringkan jahe [7], pemanfaatan energi panas buang dari kondensor AC sentral untuk pemanas air [8], pemanfaatan panas gas buang diesel sebagai energi listrik [9].

Selain itu, terkait dengan proses pengeringan yang dikaitkan dengan mutu produk, hasil penelitian diantaranya adalah bagaimana proses pengeringan batubara muda (ignite) menjadi lebih optimal dengan menambahkan superheated coal dryng system pada pembangkit listrik (power plant) sehingga pemanfaatan batubara muda menjadi lebih efisien dengan peningkatan sebesar $48 \%$ $56 \%$ [10], atau penelitian yang lain dimana hasilnya adalah proses pengeringan kentang pada greenhouse dengan metode active mode lebih baik kinejanya dbandingkan dengan passive mode [11].

Oven pengering terpasang (existing driyer oven) adalah dengan sistem tunnel driyer, dimana tray yang telah dimuati obat nyamuk bakar basah diletakkkan pada chain conveyor yang melintas di dalam oven dengan waktu tinggal (keeping time) yang sesuai untuk pengeringan obat nyamuk. Oven merupakan ruangan yang panjang dan dialiri udara panas yang ditiupkan ke dalam ruang pengering melalui lubang utama yang berada diatasnya. Udara panas berasal dari sebuah dapur dengan burner berbahan bakar solar dan dialirkan melalui instalasi pipa.

Berdasarkan gambaran dari proses pengeringan obat nyamuk bakar di atas, dan dari hasil pengamatan, peluang efisiensi untuk menekan biaya produksi adalah pada komponen biaya bahan bakar, dimana sumber panas proses pengeringan diperoleh dari sumber panas yang lain, dalam hal ini sumber panas bisa dapur dengan pemanas (burner) berbahan bakar diperoleh dari ecomonizer yang terpasang pada dapur berbahan bakar batu bara.

Rancangan modifikasi yang akan dilakukan adalah dengan memanfa'atkan sumber panas dari economizer yang mampu memasok air panas sebagai sumber panas oven pengering. Adapun mekanisme pertukaran panas yang terjadi untuk mengeringkan obat nyamuk bakar adalah pertukaran panas konveksi, dimana air panas yang berasal dari economizer dialirkan melewati Alat Penukar Panas (APK) jenis radiator lengkap dengan fan yang terpasang di oven pengering. Fungsi fan adalah mengalirkan udara luar untuk dilewatkan pada APK sehingga menghasilkan udara panas yang akan mengenai obat nyamuk bakar yang tersusun di rak. Semakin cepat kecepatan udara udara semakin cepat pula proses pengeringan atau penurunan kadar air[12], namun fenomena ini akan memunculkan masalah, dimana akan terjadi pengerasan pada permukaan lebih cepat, sebagai akibat temperatur pada permukaan meningkat sementara konduktivitas termal obat nyamuk rendah [13], dan mengakibatkan tingkat kekeringan obat nyamuk tidak merata.

Dengan dilakukan modifikasi oven pengering dengan memanfaatkan economizer, diharapkan terjadi efisiensi biayadengan tetap memperhatikan mutu produk yang ditentukan dari tingkat kekeringan. Dengan pemikiran tersebut, maka penelitian ini bertujuan untuk melakukan analisis kinerja oven pengering hasil modifikasi obat nyamuk bakar dengan variasi kecepatan aliran udara panas.

\section{Metode Penelitian}

Berdasarkan Gambar 1, proses penelitian dimulai dari melakukan modifikasi oven pengering dengan hasil seperti pada Gambar 2. Dilanjutkan dengan pekerjaan instalasi air panas dengan memanfaatkan economizer sebagai sumber panas untuk proses pengeringan obat nyamuk, seperti Gambar 3. 


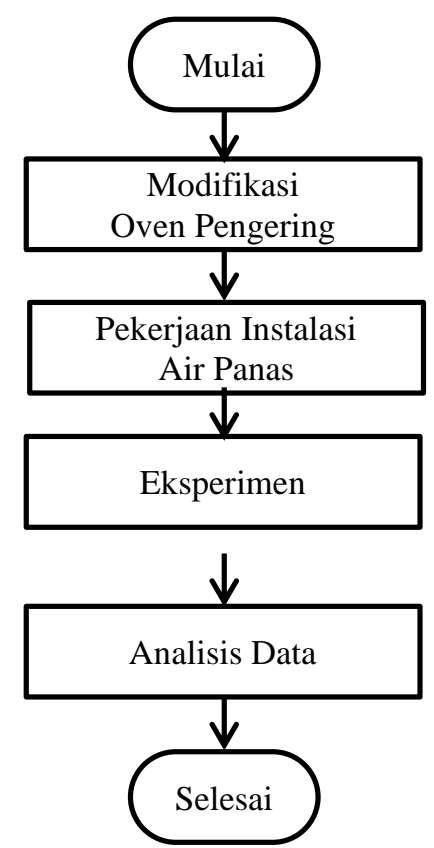

Gambar 1. Gambar Alir Penelitian

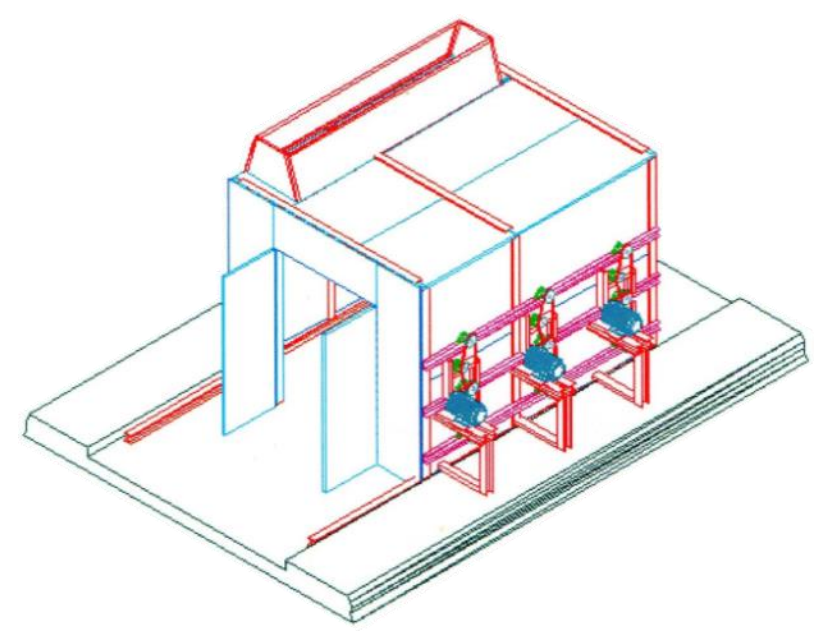

Gambar 2. Rancangan Ruang Pengering

Pada tahapan eksperimen, variabel tetapnya adalah massa obat nyamuk bakar basah sebesar 63,2 kg, temperatur air panas masuk ke sistem adalah $85^{\circ} \mathrm{C}$, laju aliran air panas $3,5 \mathrm{~m}^{3} /$ detik, waktu tinggal selama 4 jam. Eksperimen dilakukan sebanyak 3 kali dengan variasi kecepatan aliran udara panas, dengan kondisi seperti di bawah ini:

1) Eksperimen pertama: Eksperimen dengan setting kecepatan aliran udara panas $0,5 \mathrm{~m} /$ detik.

2) Eksperimen ke-2: Eksperimen dengan setting kecepatan aliran udara panas $0,7 \mathrm{~m} /$ detik.

3) Eksperimen ke-2: Eksperimen dengan setting kecepatan aliran udara panas $0,9 \mathrm{~m} /$ detik.

Adapun prosedur eksperimen adalah sebagai berikut:

1) Rak Obat nyamuk bakar dimasukkan dalam ruang pengering oven, letakkan humidity and temperature logger di atas rak.
2) Hidupkan motor sehingga fan berputar;

3) Hidupkan pompa sehingga air mengalir menuju radiator, catat temperatur air yang tertera pada stem thermometer, debit air yang tertera pada flow meter serta kecepatan aliran air dengan menggunakan ultrasonic flow meter;

4) Buka wet exhaust air hole;

5) Tutup ruang pengering dengan rapat untuk menghindari panas pada ruang pengering terlepas.

6) Waktu tinggal proses pengeringan selama 4 jam.

7) Setelah proses pengeringan selesai, ambil 2 (dua) keping obat nyamuk dari setiap tray dengan posisi letak yang sama pada setiap tray.

8) Serahkan sampel produk ke QC inspector untuk uji mutu produk (obat nyamuk bakar).

9) Lakukan hal yang sama untuk langkah 1 sampai 8 pada kondisi eksperimen yang berbeda.

Untuk mengukur kecepatan air yang mengalir di dalam pipa digunakan ultrasonic flow meter, untuk mengukur dan mencatat kondisi kelembaban dan temperatur ruang pengering digunakan humidity and temperature logger, untuk mengukur kecepatan aliran udara yang dihasilkan oleh fan digunakan anemometer, dan untuk mengukur temperatur water inlet radiator digunakan stem thermometer.

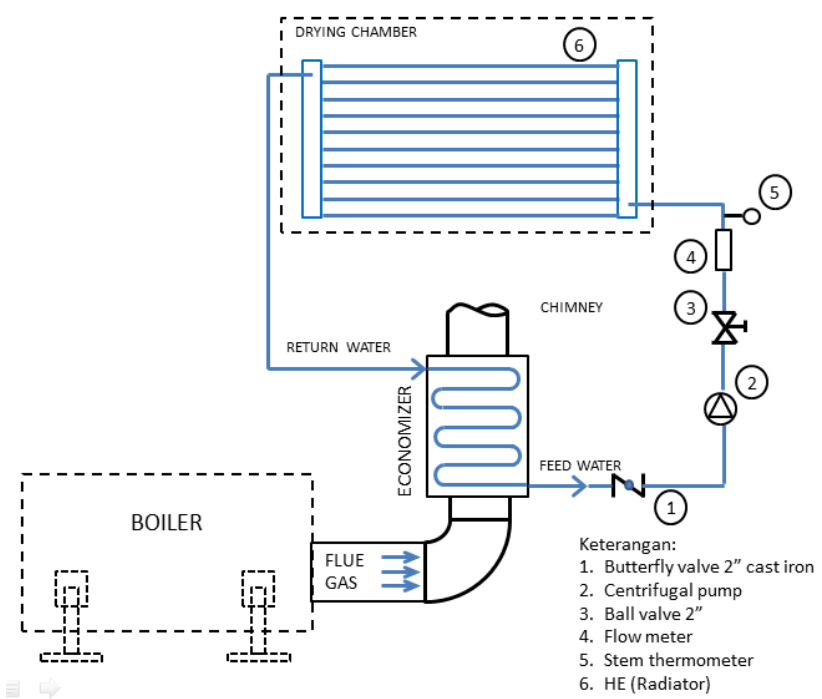

Gambar 3. Skema Instalasi Air Panas

Tahapan terakhir adalah analisis data, dimana data hasil periksa sampel yang dilakukan oleh QC inspektor dianalis. Adapun metode analisis data yang digunakan dalam penelitian ini adalah analisis uji t untuk beda dua rata-rata dengan sampel independen (independent sample $t$ test)

\section{Hasil dan Pembahasan}

Untuk menggambarkan perbedaan kondisi ruang pengering pada masing-masing eksperimen, perubahan temperatur ( $\mathrm{Tdb}$ ) dan relatitve humidity ( $\mathrm{RH})$ dibagi menjadi 3 (tiga) zona berdasarkan waktu tinggal, yaitu: 
1) Zona 1 terletak pada waktu tinggal antara menit ke-0 sampai menit ke-80.

2) Zona 2 terletak pada waktu tinggal antara menit ke80 sampai sampai menit ke-160.

3) Zona 3 terletak pada waktu waktu tinggal antara menit ke-160 sampai menit ke-240.

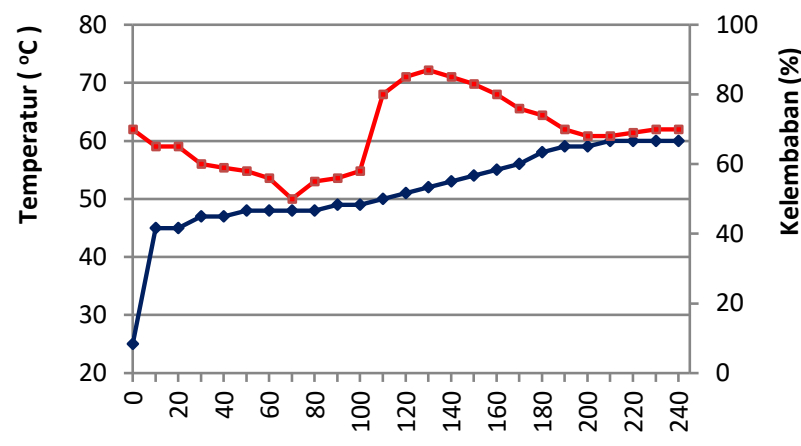

$\longrightarrow$ Temperatur (Tbd) $\quad$ Kelembaban $(\mathrm{RH})$

Gambar 3. Grafik Kondisi Ruang Pengering Eksperimen Pertama

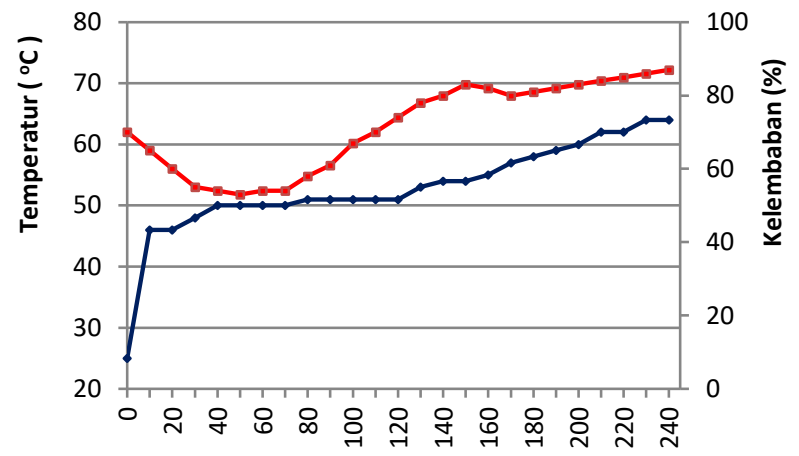

$\longrightarrow$ Temperatur (Tbd) $\quad$ Kelembaban $(\mathrm{RH})$

Gambar 4. Grafik Kondisi Ruang Pengering Eksperimen Kedua

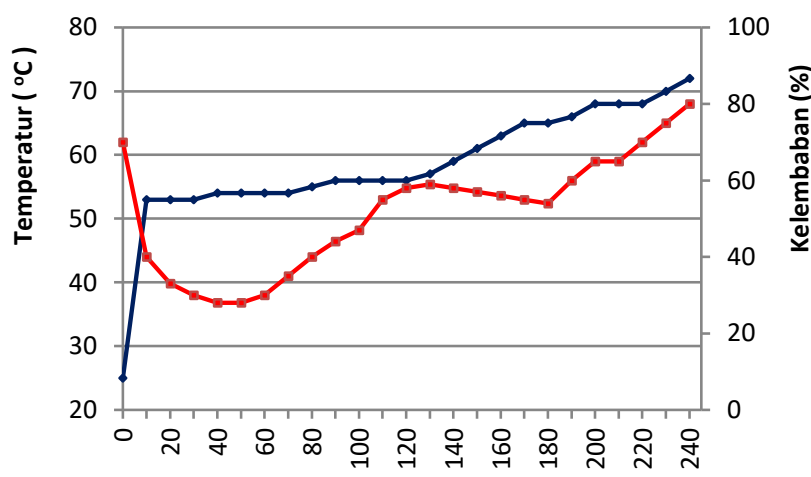

$\longrightarrow$ Temperatur (Tbd) $\quad \longrightarrow$ Kelembaban (RH)

\section{Gambar 5. Grafik Kondisi Ruang Pengering Eksperimen Ketiga}

Pada eksperimen pertama, kondisi ruang pengering pada zona 1 seperti yang terlihat pada Gambar 3, pada menit ke-0 sampai menit ke-10 dan terjadi penurunan Tdb dan terjadi penurunan RH. Kondisi ini terjadi karena pada menit-menit pertama kondisi kandungan uap air di rungan pengering masih rendah. Pada menit ke-20 sampai menit ke-80, terjadi penurunan Tdb dan peningkatan RH. Kondisi ini terjadi karena perubahan $\mathrm{Tdb}$ dan $\mathrm{RH}$ pada zona 1 dipengaruhi oleh massa kandungan air, dimana pada zona 1 massa air masih besar, sehingga kapasitas panas yang bersumber dari laju aliran udara panas 0,5 $\mathrm{m} / \mathrm{tdk}$ menguapkan kandungan air dengan massa yang besar dan akibatnya semakin banyak kandungan uap air di ruang pengering. Pada zona 2, Tdb dan RH semakin meningkat, terjadi karena massa air sudah berkurang dan uap air yang terkadung dalam ruang pengering belum terlepas melalui wet exhaust air hole, sehingga pada zona 1 terjadi kondensasi. Pada zona 3, Tdb meningkat dan RH semakin menurun, terjadi karena massa air sudah berkurang dan uap air yang terkandung dalam ruang pengering sebagian sudah terlepas melalui wet exhaust air hole. Kondisi ini menunjukkan bahwa suhu dan kecepatan udara yang lebih tinggi meningkatkan laju penguapan [14].

Pada eksperimen kedua, kondisi ruang pengering pada zona 1, seperti yang terlihat pada Gambar 4 adalah relatif sama dengan kondisi ruang pengering eksperimen pertama dengan penjelasan yang sama. Pada zona 2, Tdb terus meningkat sampai menit ke-160, sementara RH terus meningkat hanya sampai menit ke-140 dan mulai menurun pada menit ke-150, terjadi karena massa air sudah berkurang dan uap air Pada zona 2, $\mathrm{T}_{\mathrm{db}}$ dan $\mathrm{RH}$ semakin meningkat, terjadi karena massa air sudah berkurang dan uap air yang terkadung yang terkadung dalam ruang pengering sebagian sudah terlepas melalui wet exhaust air hole. Pada zona 3, $\mathrm{T}_{\mathrm{db}}$ terus meningkat, sementara itu $\mathrm{RH}$ turun sampai menit ke 180 dan mulai meninggi pada menit ke-190.

Pada eksperimen ketiga, kondisi ruang pengering pada zona 1, seperti yang terlihat pada Gambar 5 relatif sama dengan kondisi ruang pengering eksperimen pertama dan ke-2 dengan penjelasan yang sama. Pada zona 2, Tdb dan RH terus meningkat sampai menit ke-160, sementara RH terus meningkat hanya sampai menit ke-110 dan mulai menurun pada menit ke-120, terjadi karena massa air sudah berkurang dan uap air yang terkadung dalam ruang pengering sebagian sudah terlepas melalui wet exhaust air hole. Pada zona 3, Tdb terus meningkat, sementara itu RH turun sampai menit ke 180 dan mulai meninggi pada menit ke-190.

Dari hasil uji mutu produk, seperti yang tercantum pada Tabel 2, terlihat bahwa sampel produk dari hasil proses pengeringan eksperimen ke-2, semuanya dinyatakan NG (No Good) karena kadar air obat nyamuk $10 \%$ ke atas. Sementara itu, sampel produk hasil pengeringan eksperimen ke-2 dan ke-3 semuanya lolos uji atau dinyatakan OK karena kadar air produk sampel di bawah 10\%. Hasil ini menguatkan hasil pengujian yang 
menemukan bahwa tingkat kekeringan dapat dicapai lebih cepat jika laju aliran udara panas meningkat [15].

Tabel 2. Nilai Kadar Air dan Hasil Uji Mutu

\begin{tabular}{|c|c|c|c|c|c|c|}
\hline \multirow[b]{2}{*}{ Sampel } & \multicolumn{2}{|c|}{$\begin{array}{c}\text { Eksperimen } \\
\text { pertama }\end{array}$} & \multicolumn{2}{|c|}{$\begin{array}{c}\text { Eksperimen } \\
\text { Ke-2 }\end{array}$} & \multicolumn{2}{|c|}{$\begin{array}{c}\text { Eksperimen } \\
\text { Ke-3 } \\
\end{array}$} \\
\hline & $\begin{array}{c}\text { Kadar } \\
\text { Air } \\
(\%)\end{array}$ & $\begin{array}{c}\text { Hasil } \\
\text { Uji }\end{array}$ & $\begin{array}{c}\text { Kadar } \\
\text { Air } \\
(\%)\end{array}$ & $\begin{array}{c}\text { Hasil } \\
\text { Uji }\end{array}$ & $\begin{array}{c}\text { Kadar } \\
\text { Air } \\
(\%)\end{array}$ & $\begin{array}{c}\text { Hasil } \\
\text { Uji }\end{array}$ \\
\hline 1 & 12 & $\mathrm{NG}$ & 8 & OK & 7 & OK \\
\hline 2 & 14 & NG & 9 & OK & 6 & OK \\
\hline 3 & 13 & NG & 7 & OK & 7 & OK \\
\hline 4 & 10 & NG & 6 & $\mathrm{OK}$ & 6 & OK \\
\hline 5 & 13 & NG & 7 & $\mathrm{OK}$ & 5 & OK \\
\hline 6 & 15 & NG & 6 & OK & 6 & OK \\
\hline 7 & 12 & NG & 8 & OK & 5 & OK \\
\hline 8 & 13 & NG & 9 & OK & 6 & OK \\
\hline 9 & 12 & NG & 6 & OK & 7 & OK \\
\hline 10 & 15 & $\mathrm{NG}$ & 7 & OK & 6 & OK \\
\hline 11 & 13 & NG & 8 & OK & 5 & OK \\
\hline 12 & 14 & NG & 8 & OK & 6 & OK \\
\hline 13 & 13 & NG & 6 & OK & 4 & OK \\
\hline 14 & 12 & NG & 7 & OK & 7 & OK \\
\hline 15 & 12 & NG & 9 & OK & 6 & $\mathrm{OK}$ \\
\hline
\end{tabular}

Dari hasil uji hipotesis independent sample t-test dengan asumsi varian homogen (melalui uji F) dan $\alpha=$ 0,05 , menunjukkan bahwa tingkat kekeringan produk hasil eksperimen ke-2 berbeda dengan tingkat kekeringan hasil eksperimen ke-3, atau dengan kata lain produk lain hasil ekperimen ke-3 lebih kering daripada produk eksperimen ke-2. Kecepatan aliran udara panas sebesar $9 \mathrm{~m} / \mathrm{detik}$ mampu mengeringkan produk secara ideal, dimana tidak terjadi pengerasan pada permukaan sebagai akibat laju pengeringan yang terlalu cepat.

\section{Kesimpulan}

Pada eksperimen pertama terjadi kondensasi pada ruang pengering, sementara pada eksperimen ke-2 dan ke-3 tidak terjadi. Dari hasil pengujian mutu produk, sampel produk hasil eksperimen pertama semuanya dinyatakan NG, sementara sampel produk hasil eksperimen ke-2 dan ke-3 semuanya dinyatakan OK. Dari uji hipotesis independent sample t-test dengan asumsi varian homogen (melalui uji F) dan $\alpha=0,05$ menyimpulkan tingkat kekeringan produk hasil eksperimen ke-3 lebih baik dari produk hasil eksperimen ke-2. Sehingga, setting laju aliran udara panas sebesar $9 \mathrm{~m} / \mathrm{dtk}$ menghasilkan unjuk kerja oven pengering hasil modifikasi yang paling optimal.

\section{Daftar Pustaka}

[1] Bisnis.com, "Nilai Pasar Obat Nyamuk Diperkirakan Sentuh Rp 5 Triliun," 18 Oktober 2018. [Online]. Available:

https://ekonomi.bisnis.com/read/20181018/257/850782/nil ai-pasar-obat-nyamuk-diperkirakan-sentuh-rp5-triliun..
[Diakses 9 Juni 2020].

[2] J. Fahmi, "Analisis Perbandingan Sikap Konsumen Atas Atribut Produk Obat Nyamuk Merek Baygon dan Hit Di Kota Pekanbaru," Jom Fekon, vol. 2, p. 2, 2015.

[3] E. Listra, "The Concept of Competition and The Objectives of Competitors," dalam 20th International Scientific Conference Economics and Management - 2015 (ICEM-2015), 2015.

[4] R. D. Banker, R. Mashruwala dan A. Tripathy, "Does a differentiation strategy lead to more sustainable financial performance than a cost leadership strategy?," Management Decision, vol. 52, no. 5, pp. 872-896, 2014.

[5] M. Kharub, R. S. Mor dan R. Sharma, "The relationship between cost leadership competitive strategy and firm performance: A mediating role of quality management," Journal of Manufacturing Technology Management and firm performance, 2019.

[6] H. Jouhara, N. Khordehgah, S. Almahmoud, A. Chauhan dan S. A. Tassou, "Waste heat recovery technologies and applications," Thermal Science and Engineering Progress, vol. 6, pp. 268-289, 2018.

[7] N. Lestari, Samsuar, E. Novitasari dan K. Rahman, "Kinerja Cabinet Dryer pada Pengeringan Jahe Merah dengan Memanfaatkan Panas Terbuang Kondensor Pendingin Udara," Jurnal Agritechno, vol. 13, no. 1, pp. 57-70, 2020.

[8] A. Aziz, J. Harianto dan A. K. Mainil, "Potensi Pemanfaatan Energi Panas Terbuang Pada Kondensor AC Sentral Untuk Pemanas Air Hemat Energi," Jurnal Mekanikal, vol. 6, no. 2, pp. 569-576, 2015.

[9] S. Klara dan Sutrisno, "Pemanfaatan Panas Gas Buang Mesin Diesel Sebagai Energi Listrik," Jurnal Riset dan Teknologi Kelautan (JRTK), vol. 14, no. 1, 2016.

[10] M. Jaszczur, M. Dudek, M. A. Rosen dan Z. Kolenda, “An analysis of integration of a power plant with a lignite superheated steam drying unit," Journal of Cleaner Production, vol. 243, 2020.

[11] O. Prakash, A. Kumar dan V. Laguri, "Performance of modified greenhouse dryer with thermal energy storage," Energy Reports, vol. 2, pp. 155-162, 2016.

[12] R. Sary, "Kaji Eksperimental Pengeringan Biji Kopi Dengan Menggunakan Konveksi Paksa," Jurnal Polimesin, vol. 14, no. 2, pp. 13-18, 2016.

[13] R. P. F. Guin é, "The Drying of Foods and Its Effect on the Physical-Chemical, Sensorial and Nutritional Properties," International Journal of Food Engineering, vol. 4, no. 2, pp. 93-100, 2018.

[14] R. N. Putra dan T. A. Ajiwiguna, "Influence of Air Temperature and Velocity for Drying Process," dalam Engineering Physics International Conference, EPIC 2016 , 2017.

[15] I. B. Alit dan I. G. B. Susana, "Pengaruh Kecepatan Udara Pada Alat Pengering Jagung Dengan Mekanisme Penukar Kalor," Rekayasa Mesin, vol. 11, no. 1, pp. 77-84, 2020. 